\title{
Røntgenpulverdiffraktion - 90 år med Debye-Scherrer-metoden
}

Af professor emeritus Svend Erik Rasmussen, Geologisk Institut, Aarhus Universitet.

Med Bragg's lov og Debye-Scherrer-metoden åbnedes nye døre for identifikation af kemiske forbindelser ved anvendelse af røntgenpulverdiffraktion. I dag er der registreret 186.000 forbindelser.

I 1912 fandt M. von Laue sammen med P. Knipping og W. L. Friedrich, at røntgenstråling spredes fra krystaller efter et interferensprincip, således at spredningen er begrænset til bestemte vinkler. Heraf kunne der drages to konklusioner:

1. Røntgenstråling måtte opfattes som en bølgebevægelse.

2: Krystallers atomer er arrangeret systematisk, som $i$ et gitter.

Figuren til højre viser et eksempel på krystalgitre, og på hvordan planer kan tilordnes sådanne gitre.

\section{Bragg's lov}

W. L. Bragg viste i 1913, at spredningen af røntgenstråling kunne opfattes som en refleksion af strålingen i planer gennem krystallen, som antydet i figuren nedenfor til venstre, og at betingelsen for refleksion kunne udtrykkes ved ligningen: $\lambda=2 \mathrm{~d} \sin \theta$, hvor $\lambda$ er strålingens bølgelængde, $\theta$ er refleksionsvinklen og $\mathrm{d}$ afstanden mellem

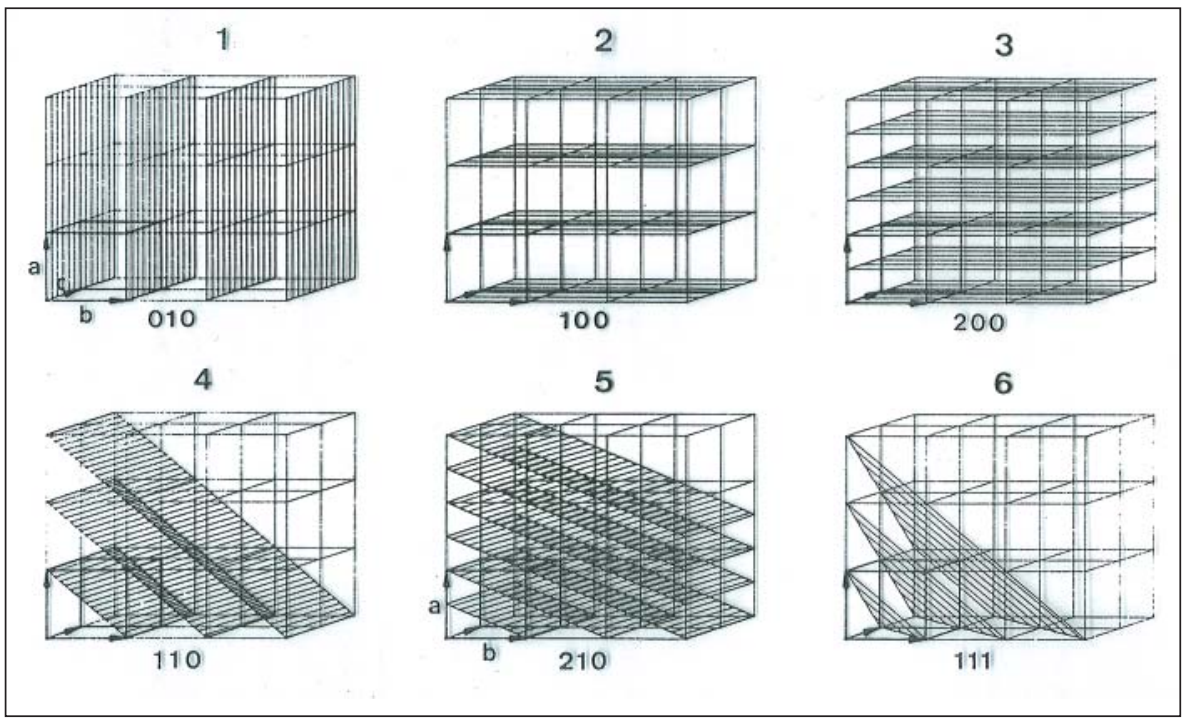

Krystalgitre og tilordnede planer. (Grafik: Venligst udlånt af docent emer. Rita Hazell, Kemisk Institut, Aarhus Universitet)

de reflekterende planer. Figuren nedenfor til højre viser princippet for et instrument, der bygger på anvendelsen af ovenstående formel.

\section{Debye-Scherrer-metoden}

I Göttingen samme år beregnede den unge hollænder Petrus Josephus Wilhelmus Debije, der senere ændrede sit navn til Peter Debye, hvordan intensiteten af den spredte røntgenstråling fra krystaller afhænger af temperaturen. I 1915 publicerede han en teoretisk afhandling, hvori han viste, at mo- nokromatisk røntgenstråling ville spredes fra elektroner i et atom på en sådan måde, at der optræder vinkelafhængige maxima og minima i den spredte stråling. På det tidspunkt opfattede man endnu elektroner som nærmest punktformede partikler.

Det fysiske institut i Göttingen havde under første verdenskrig (1914-1918) formentlig meget få studenter og unge lærere. Som hollænder var Debye imidlertid fritaget for tysk militærtjeneste. En af instituttets få studenter var Paul Scherrer, der var schweizer. I 1916 publicerede han og Debye en

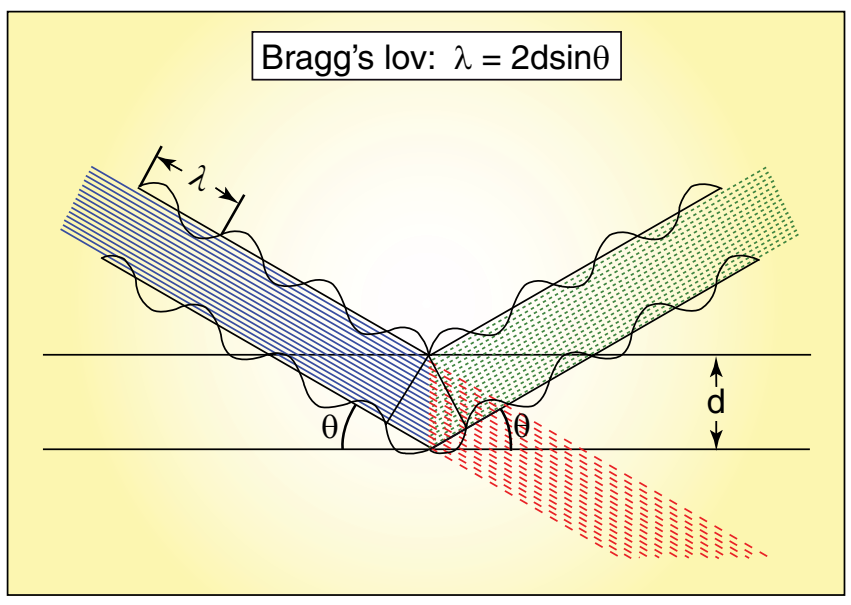

Bragg's lov. (Grafik: UVH efter udlceg; venligst udlånt af docent emer. Rita Hazell, Kemisk Institut, Aarhus Universitet)

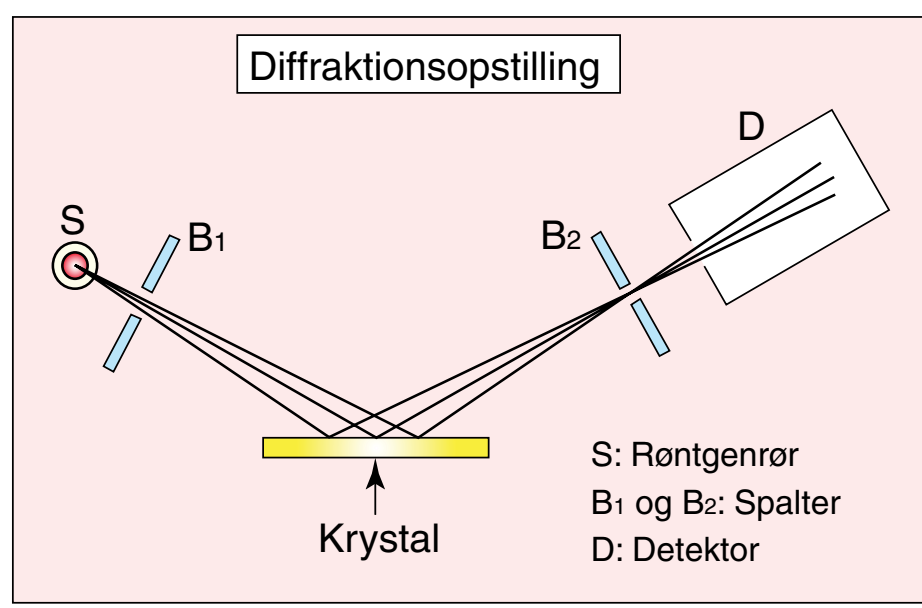

Røntgeninstrument der bygger på Bragg's lov. (Grafik: UVH efter forleg af ukendt oprindelse) 

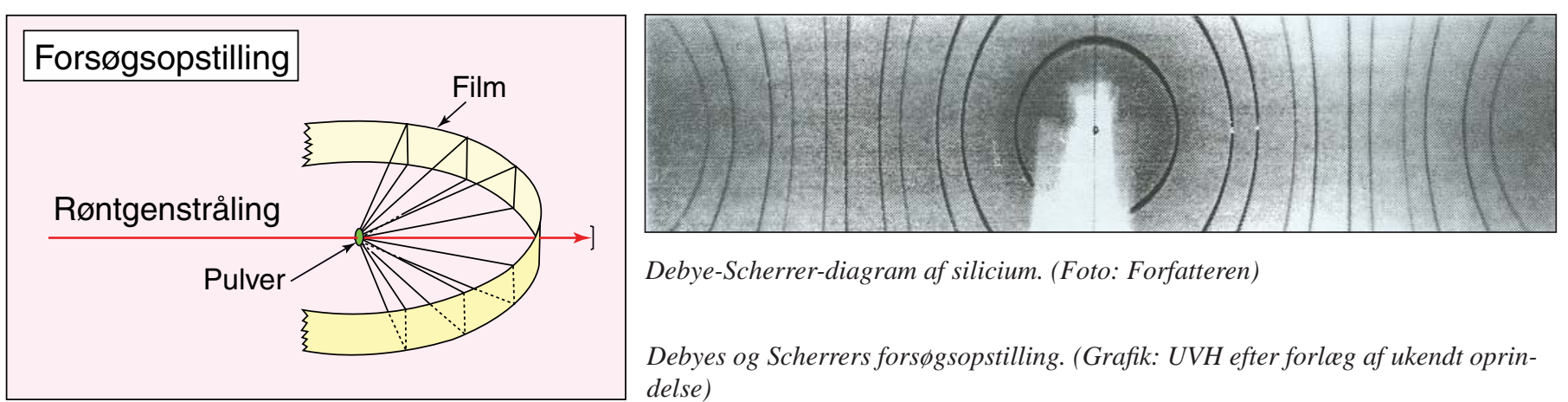

Debye-Scherrer-diagram af silicium. (Foto: Forfatteren)

Debyes og Scherrers forsøgsopstilling. (Grafik: UVH efter forlag af ukendt oprindelse)

afhandling, der oprindeligt havde til formål at efterprøve de formler, som Debye havde udledt året før. Deres forsøgsopstilling er skitseret i figuren ovnefor til venstre.

Den pulverformige prøve blev presset til en cylinder med diameter $2 \mathrm{~mm}$ og længde $10 \mathrm{~mm}$ og anbragt $\mathrm{i}$ centrum af en cylinder med radius $57 \mathrm{~mm}$. Monokromatisk røntgenstråling blev sendt ind mod prøven gennem en kollimator, en blycylinder, hvorigennem der var boret et hul på $2,5 \mathrm{~mm}$ i diameter. Den spredte stråling blev registreret på en film spændt op mod cylinderens indre væg. Til deres overraskelse fandt Debye og Scherrer, at deres film oven på en baggrund af vekslende størrelse også viste skarpe, veldefinerede linier. Figuren ovenfor til højre viser et diagram af polykrystallinsk silicium optaget med et kamera af DebyeScherrer-typen.

De påviste, at linierne fremkom som resultat af, at der blandt de mange små krystalkorn altid var nogle, der lå på en sådan måde, at Bragg's lov var opfyldt for de planer, man kan lægge igennem krystalgitret. De konkluderede også, at man ved deres metode kunne skelne mellem mikrokrystallinske og egentligt amorfe stoffer.
I 1917 lavede A. W. Hull ved General Electric's forskningslaboratorium i USA eksperimenter, der var analoge med Debyes og Scherrers. På grund af krigen kendte han intet til deres publikationer. Hull bestemte en del simple krystalstrukturer ved hjælp af pulvermetoden, men forlod efter et par år røntgenkrystallografien til fordel for elektronikken. Hans navn blev ikke knyttet til pulvermetoden på samme måde som Debyes og Scherrers, omend man i det engelske sprogområde længe talte om Debye-Scherrer-Hull-metoden, men denne navnekonstellation var nok for lang.

\section{Pulverdiffraktometret}

De grundlæggende principper i DebyeScherrer-metoden anvendes den dag i dag i både røntgen-, neutron- og synkrotronstråleinstrumenter, omend den fotografiske film nu er erstattet med forskellige typer af elektronisk registrering.

Også andre typer af instrumenter er blevet anvendt til pulverdiffraktion. Instrumentet afbildet i figuren nederst til højre på foregående side kan med mindre modifikationer også anvendes til pulverdiffraktion, og instrumenter baseret på det grundlag er i dag måske de mest udbredte til det formål. Den personlige computer er i dag standard som styrings- og dataopsamlingsudstyr for pulverdiffraktometre.

Ofte opsamler man 50 - 100 datapunkter pr. grad over vinkelintervaller på $60^{\circ}-130^{\circ}$ Et sådant datasæt betegnes i almindelighed som et diffraktogram. Figuren nedenfor viser et eksempel på et diffraktogram af kemisk rent $\mathrm{TiO}_{2}$. Titandioxid eksisterer $\mathrm{i}$ tre krystalformer: rutil, anatas og brookit. Diagrammet viser, at den undersøgte prøve hovedsageligt består af rutil samt af et par procent anatas.

\section{Primært analytisk hjælpeværktøj}

Røntgenpulverdiffraktion blev i de første år efter metodens fremkomst hovedsageligt brugt til strukturanalyse af simple krystalstrukturer. Ved hjælp af denne teknik bestemte V. M. Goldschmidt i Norge sammen med en gruppe af unge assistenter en række simple krystalstrukturer, der dannede grundlaget for Goldscmidts berømte værk: "Geochemische Verteilungsgesetze der Elemente."

Den største udbredelse fik metoden imidlertid som analytisk hjælpeværktøj i
Diffraktogram der viser titandioxid, rutil iblandet lidt anatas. (Kilde: Forfatteren)

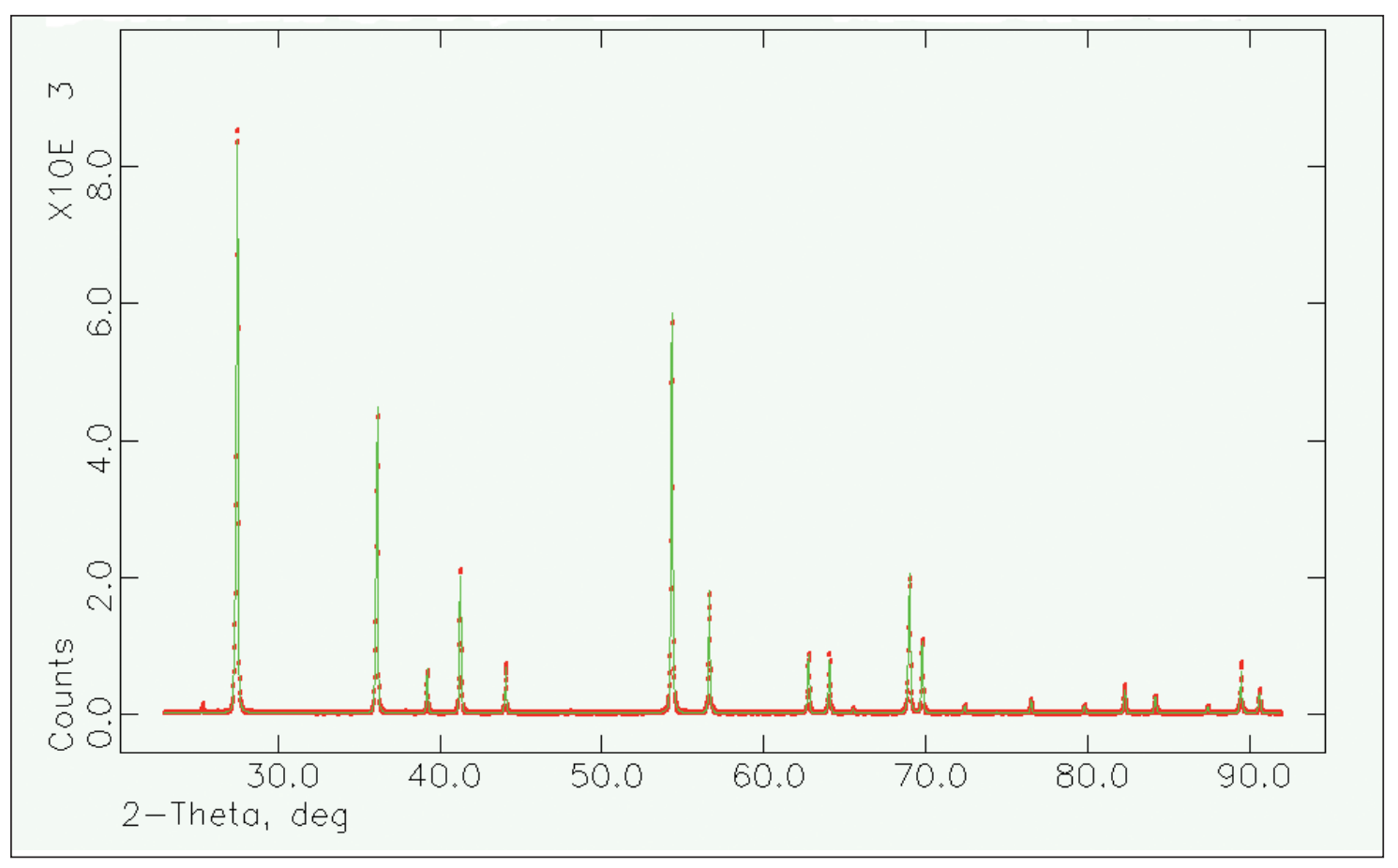


kemi og mineralogi. I 1938 publicerede J. D. Hanawalt, H. W. Rinn og L. K. Frevel fra Dow Chemical Co. diffraktionsdata for 1.000 rene, kemiske forbindelser og en metode til at udnytte denne database til identifikationsformål. Udgangspunktet var ovennævnte Bragg's lov:

$$
\lambda=2 \mathrm{~d} \sin \theta
$$

Man ser heraf, at spredningsvinklen $\theta$ afhænger af bølgelængden $\lambda$, men at netplanafstanden, d, er uafhængig af disse størrelser, idet den er knyttet til krystallens struktur. Hanawalt et al. tabulerede d-værdierne, angivet i $\AA$-enheder, efter faldende værdier, altså efter stigende vinkler. Linieintensiteterne blev angivet på den måde, at den stærkeste linie blev tildelt værdien 100 og de øvrige liniers intensitet som en procentdel af denne linies styrke. Endvidere angav man d-værdierne for de tre stærkeste linier, samt optiske og krystallografiske data.

Systemet blev senere overtaget og videreført af A. S. T. M.: American Society for Testing Materials, der udgav databasen på kartotekskort, som vist på figuren ovenfor. Værdierne for de tre stærkeste linier blev brugt til et indeks, der var udgangspunktet for en søgning i databasen. Når der er flere faser tilstede i en pulverprøve, giver hver fase sit diagram uafhængigt af tilstedeværelsen af andre faser. Det er baggrunden for, at man siger, at et stofs pulverdiagram kan opfattes som stoffets "fingeraftryk". Figuren

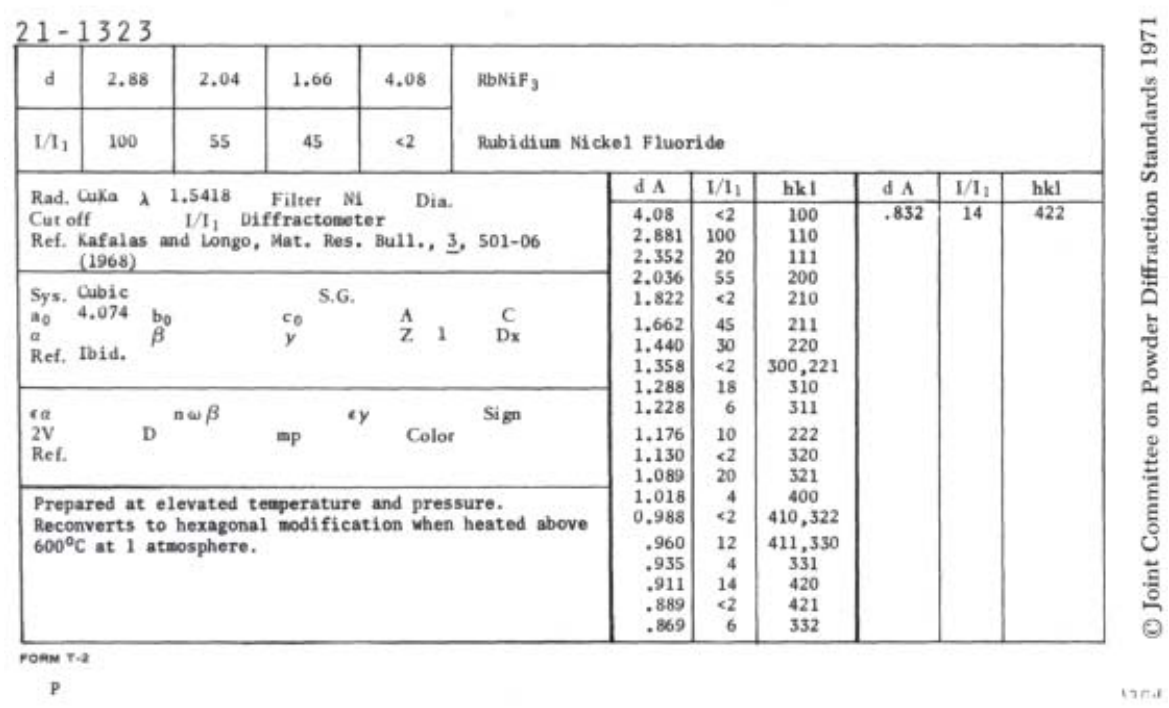

Eksempel på kartotekskort. (Kopi af kartotekskort fra American Society for Testing Materials)

nedenfor viser et eksempel på diffraktogrammer af henholdsvis rent kvarts, rent calcit og en blanding af kvarts og calcit.

\subsection{0 registrerede forbindelser}

I dag udgives og vedligeholdes databasen af International Center for Diffraction Data: I. C. D. D. et "non for profit" institut beliggende i U SA. Databasen er naturligvis for længst blevet digitaliseret og distribueres, dvs. sælges på denne form, som regel på en CD-ROM, ligesom der findes programmel til søgning i databasen. Der er nu 186.000 forbindelser registreret, og der findes partielle sektioner for mineraler, metaller, uorganiske og organiske forbindelser og farmaceutiske produkter. Udviklingen har medført, at man med en moderne personlig computer hurtigt og effektivt kan udnytte databasen.

Identifikation af et rent stof, der er registreret $i$ databasen, er i dag en ren rutineopgave, men ofte står kemikere og især geologer over for den opgave at analysere

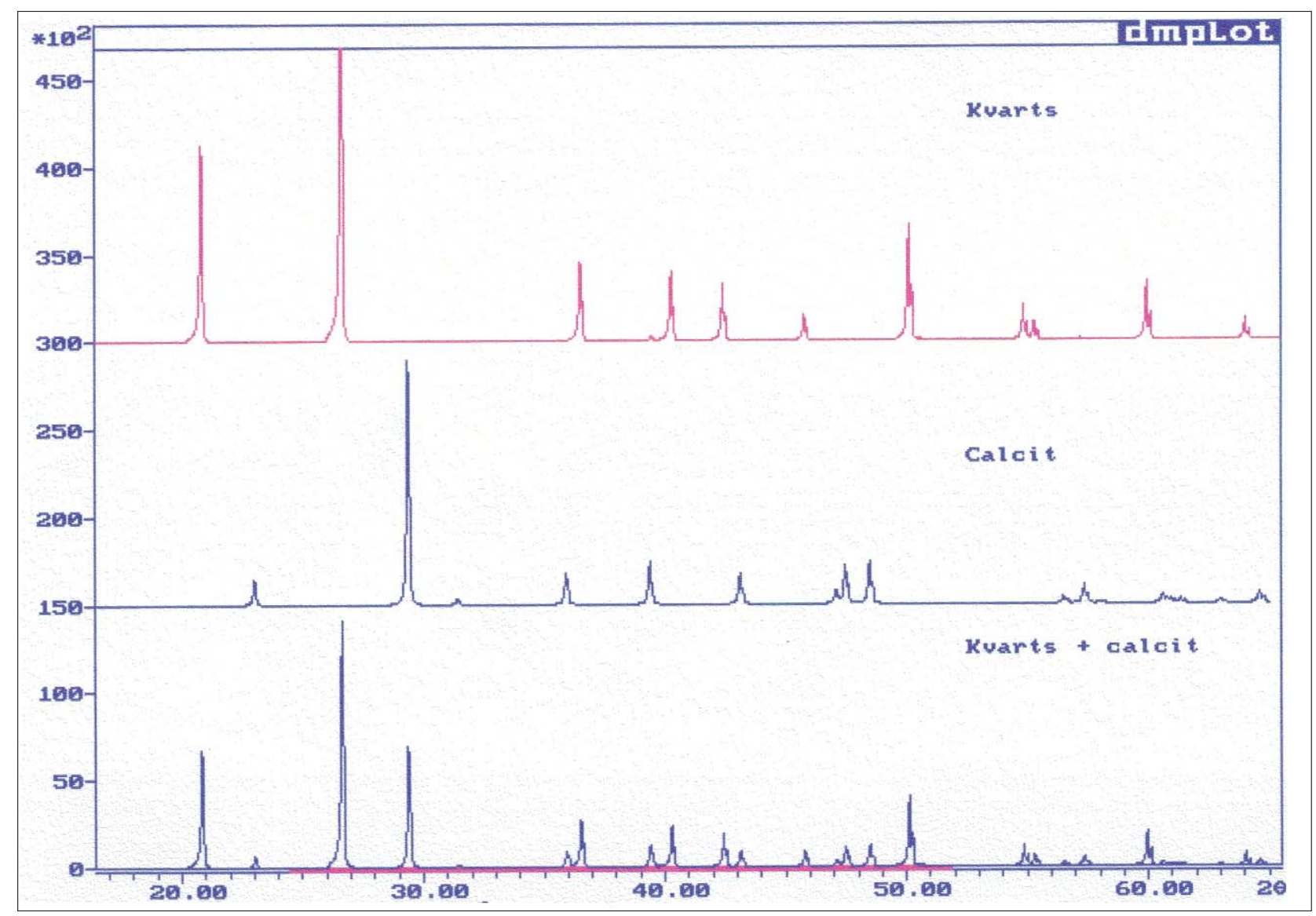

Eksempel på diffraktogrammer af ren kvarts, ren calcit samt en blanding af kvarts og calcit. (Kilde: Forfatteren) 
flerfasesystemer, og også gerne at kunne give en kvantitativ analyse af faserne. Mineraloger har i mange år med held anvendt polarisationsmikroskopet til identifikation af mineraler og også til kvantitative evalueringer, men også her har røntgendiffraktion bidraget til øget sikkerhed i analysen. Den teknologiske udvikling har ført til, at det er muligt at anvende både store datamængder og raffinerede programsystemer på relativt billige personlige computere. Som regel er anskaffelse af database og tilhørende programmel en større udgift en købet af en computer.

\section{Røntgendiffraktion i Danmark}

I Danmark begyndte mineralogen $\mathrm{H}$. Clausen i 1920-tallet at arbejde med metoden, men det blev den Kongelige Veterinær- og Landbohøjskole, der i en årrække var centret for anvendelsen af røntgendiffraktion. Den visionære leder af Landbohøjskolens kemiske Laboratorium, Niels Bjerrum, så tidligt anvendelsesmulighederne for denne ny teknik og opmuntrede sin unge assistent Aksel Tovborg Jensen til at specialisere sig inden for dette område.

Tovborg arbejdede med både énkrystalog pulvermetoder. Der var dengang ingen formaliseret uddannelse i røntgenkrystallografi noget sted i Danmark. Tovborg uddannede sig i denne disciplin ved studieophold i Uppsala og ved flere ophold ved engelske universiteter. Senere tjente han som lærer og inspirator for unge videnskabsmænd/ kvinder fra videnskabelige laboratorier i København. I begyndelsen var det især uorganiske materialer, herunder mineraler, der blev undersøgt ved røntgendiffraktion, men omkring 1950 begyndte den farmaceutuddannede Bodil Jerslev at anvende pulverdiffraktion på organiske, især farmaceutiske produkter.

Ved Aarhus Universitet har pulverdiffraktion været $i$ brug rutinemæssigt siden 1960 på Kemisk Institut og siden 1967 på Geologisk Institut. Her forventer man i løbet af efteråret, at udskifte et ældre diffraktometer med et moderne, fuldautomatisk instrument af en type som vist på figuren ovenfor.

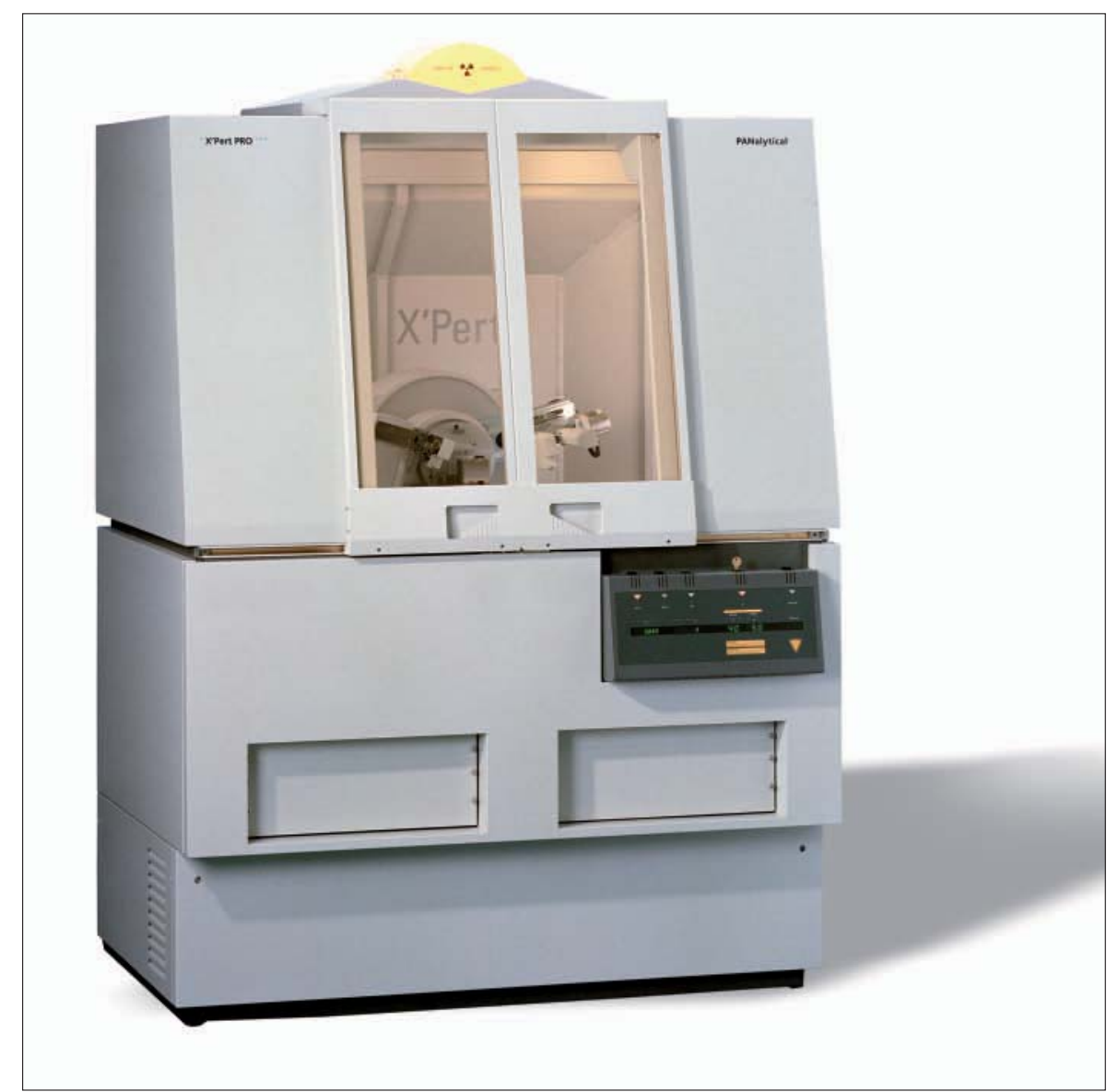

Fuldautomatisk diffraktometer af typen X'Pert PRO. (Venligst udlånt af: Pananalytical)

\section{Flerfasesystemer}

Bestemmelsen af en kemisk forbindelses struktur ud fra røntgenkrystallografiske målinger er ikke en rutineopgave, men et pulverdiffraktogram kan helt entydigt beregnes ud fra en kendt struktur.

For et flerfasesytem, hvor strukturerne af de enkelte faser er kendte, kan man beregne diffraktogrammet for systemet som helhed, og bestemme de relative mængder af de indgående forbindelser ved at tilpasse observerede intensiteter med beregnede ved iterative metoder. En udbredt metode kaldet Rietveld-metoden efter en hollandsk videnskabsmand, der oprindeligt anvendte den til forfining af atompositioner i krystalstruk- turanalyser. Metoden er endnu ikke en ren rutinemetode, men erfarne brugere kan opnå resultatet, der ikke eller kun vanskeligt kan opnås med andre metoder. Til denne metode findes der flere særdeles gode "Public Domain" dvs. gratis programmer, der kan fås via Internettet.

\section{Rietveld-metoden}

Rietveld-metoden kan også bruges til at gøre identifikationen af de enkelte faser i et flerfasesystem mere sikker. Som et eksempel fra geologiens verden kan nævnes, at Mette Kølbæk Christensen i sit speciale under H. D. Zimmermanns vejledning foretog en undersøgelse af bornholmsk granit. 


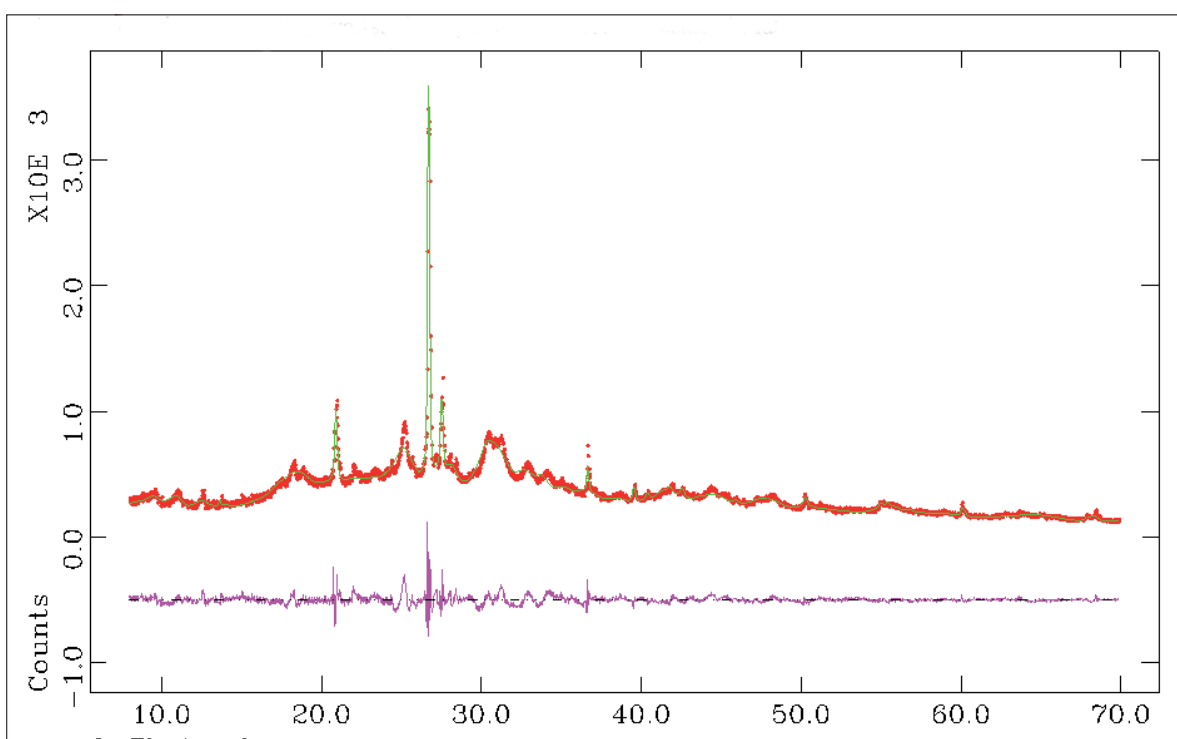

2-Theta, deg

Mouse (keyboard): Left(H) - Height, Right(w) - Location Both(X) - exit

Bornholmsk granit med kvarts, allanit, albit, cronstedtit, bastncesit og labradorit Observerede data: røde; beregnede data: grønne. Nederst ses differenskurven. Y-aksen viser antal tcellinger og X-aksen viser spredningsvinklen. (Kilde: Forfatteren)

Det var relativt let at fastslå forekomsten af kvarts og feldspatter, men det var en stor hjælp i den følgende analyse, at kvantitative beregninger af disse faser gjorde det muligt at identificere de øvrige komponenter. Blandt disse fandt man allanit, cronstedtit og bastnæsit. Sidstnævnte mineral har den kemiske betegnelse $\mathrm{CeCO}_{3} \mathrm{~F}$, hvor cerium $\mathrm{i}$ større eller mindre omfang kan være substitueret med andre sjældne jordarter. Thorium kan også være tilstede i små mængder. Den radioaktive stråling fra thorium, især $\alpha$-strålingen, nedbryder til en vis grad bastnæsitens krystalgitter, hvilket fører til forbredning af diffraktionslinierne fra dette mineral - dette kan ses på figuren ovenfor, der viser en Rietveld-forfining fra en af ovennævite prøver.

\section{Ny renæssance}

Udviklingen af røntgendiffraktometre og af synkrotronstrålingsfaciliteter har medført, at pulverdiffraktion har fået en vis renæssance som metode til strukturanalyse for forbindelser, der vanskeligt eller slet ikke kan opnås i form af tilstrækkeligt store énkrystaller.

Det er tankevækkende for diskussioner om styring af forskning at betragte dette eksempel, som blot er et af mange, på hvordan forskning, der som udgangspunkt har abstrakte teoretiske modeller, fører til resultater, der senere viser sig at være af særdeles praktisk betydning.

Denne artikel vil også blive bragt i modificeret form i Dansk Kemi.

\section{Biografisk information}

Petrus Josephus Wilhelmus Debije, (Peter Debye), blev født i Holland (Maastricht) i 1884. Han studerede først elektroteknik i Aachen, tog derefter en doktorgrad i fysik i München og skabte sig hurtigt et navn som teoretisk fysiker. I 1911 efterfulgte han Einstein som professor i fysik ved universitetet i Zürich, blev året efter professor i Utrecht, og i 1913 blev han kaldet til en lærestol i Göttingen.

Debye vendte i 1920 tilbage til Zürich, denne gang til E. T. H. Der gjorde han sit navn kendt inden for den fysiske kemi med et bidrag til beregning af aktivitetskoefficienter: Debye-Hückel-teorien. I 1927 modtog han en kaldelse til et professorat i Leipzig og i 1934 en kaldelse til Berlin. I 1936 fik han nobelprisen i kemi for sine bidrag til bestemmelse af molekylers struktur.

I 1939 rejste han via Holland til USA og blev ansat ved Cornell University. Han blev aldrig tysk statsborger, men blev amerikansk statsborger i 1946 og døde i USA i 1966.

Paul Scherrer, født 1890 i Schweiz, viste i 1918, at krystalkorn, der er mindre end ca. $100 \mathrm{~nm}$, gav bredere diffraktionslinier end normalt, og at man kunne benytte linieforbredningen til måling af krystallitstørrelse. Han blev professor i fysik i Zürich i 1920 som trediveårig. Senere gik han ind i kernefysik og blev en ivrig fortaler for kerneenergi. Han døde i Zürich i 1969. 